\title{
A Novel Model of Cancer
}

\author{
Hans W. Giertz \\ GiertzTech, Gnesta, Sweden \\ Email: hans@miklagaard.com
}

How to cite this paper: Giertz, H.W. (2018) A Novel Model of Cancer. Journal of Cancer Therapy, 9, 383-387.

https://doi.org/10.4236/jct.2018.95034

Received: February 2, 2018

Accepted: May 5, 2018

Published: May 8, 2018

Copyright $\odot 2018$ by author and Scientific Research Publishing Inc. This work is licensed under the Creative Commons Attribution International License (CC BY 4.0).

http://creativecommons.org/licenses/by/4.0/

\begin{abstract}
This study describes a novel model of cancer. Cancer is caused, according to this model, by two toxic molecules, $\mathrm{COF}_{2}$ (carbonyl fluoride) and $\mathrm{CS}_{2}$ (carbon disulfide). $\mathrm{COF}_{2}$ acts as a catalyst and produces $\mathrm{CS}_{2}$. $\mathrm{CS}_{2}$ acts as a catalyst and produces $\mathrm{COF}_{2}$. Hence, the molecules $\mathrm{COF}_{2}$ and $\mathrm{CS}_{2}$ have the ability to reproduce each other, i.e. to create a chain reaction where $\mathrm{COF}_{2}$ and $\mathrm{CS}_{2}$ are multiplied. $\mathrm{COF}_{2}$ and $\mathrm{CS}_{2}$ are toxic. It is proposed that long-term cell exposure to $\mathrm{COF}_{2}$ and $\mathrm{CS}_{2}$ may disturb cell apoptosis and cause uncontrolled cell growth, i.e. cancer. Consequently, cancer is caused by a disease causing mechanism or agent and not by a pathogen. However, cancer can be initiated by e.g. a bacteria or virus that contains the molecules $\mathrm{COF}_{2}$ and $\mathrm{CS}_{2}$, wherein these molecules start a chain reaction producing $\mathrm{COF}_{2}$ and $\mathrm{CS}_{2}$ in the infected area and where the result can be cancer. The study describes why $\mathrm{Fe}_{2} \mathrm{O}_{3}$ (iron (III) oxide) may have a therapeutic effect on cancer.
\end{abstract}

\section{Keywords}

Cancer Model ,Cancer Marker, Cancer Therapy, Catalyzes, Carbonyl Fluoride, Carbon Disulfide, $\mathrm{Fe}_{2} \mathrm{O}_{3}$, Ferumoxytol

\section{Introduction}

The present report describes a novel model of cancer. According to this model cancer is caused by a mechanism consisting of two toxic molecules. It is proposed that they impair the immune system. A new method is described that facilitates non-invasive analyses of these two molecules in cancer cell lines and tumors in vivo. These molecules create catalyzes, also in a test tube positioned outside the cell line or tumor. The result is analyzed and provides a description of the mechanism causing cancer.

Within medicine enzyme catalyzes is the increase in the rate of a chemical reaction by the active site of a protein. However, the human organism, pathogens, molecules and chemical elements encompass a much larger range of dif- 
ferent types of catalyzes. Catalyzes can create new molecules and where the catalyst is another molecule, compound or chemical element [1]. Molecules and chemical elements can act as catalysts where the catalytic reaction is reduction (destruction) of molecules [2]. Catalyzes is caused by radiated energy from molecules and chemical elements and generates reactions also at distance, similar to the electrons field [3].

Recent development displays that many pathogens (e.g. bacteria, virus) as well as autoimmune diseases contain a generic part that consists of the molecules $\mathrm{COF}_{2}$ and $\mathrm{CS}_{2}$. This will be reported in separate studies.

An overwhelming body of evidence displays that relationship among certain bacteria and cancer exists [4]. Chronic gastritis induced by Helibacter pylori is the strongest known risk factor for gastric cancer [5]. An estimated 15\% of all human cancers worldwide may be attributed to viruses [6] [7]. Several studies have shown that a history of autoimmune diseases increases the risk of cancer [8], despite the fact that cancer and autoimmune diseases are fundamentally different pathological conditions [9].

Numerous reports display that the molecule $\mathrm{Fe}_{2} \mathrm{O}_{3}$ increases cellular necrosis, increases the rate of apoptosis [10] and significantly inhibits cellular growth [11]. $\mathrm{Fe}_{2} \mathrm{O}_{3}$ is the active substance in Ferumoxytol [12]. Ferumoxytol is an FDA-approved therapeutic for the treatment of anemia. However, reports display that it also may be effective in treatment of various forms of cancer [13] [14].

\section{Novel Model of Cancer}

Cancer is caused, according to this model, by two molecules $\mathrm{COF}_{2}$ and $\mathrm{CS}_{2}$. Presence of $\mathrm{COF}_{2}$ and $\mathrm{CS}_{2}$ in cancer cell lines and tumors/metastases in vivo can be measured by their radiated frequency spectrum (using frequency spectrometry). However, they can also be measured using catalyzes and that is described below.

$\mathrm{COF}_{2}$ acts as catalyst and where it creates $\mathrm{CS}_{2}$ in cell lines and in tumors in vivo. $\mathrm{CS}_{2}$ also acts as catalyst and where it creates $\mathrm{COF}_{2}$ in cell lines and in tumors in vivo. Consequently, a small amount of $\mathrm{COF}_{2}$ acts as catalyst and creates $\mathrm{CS}_{2}$, which in its turn creates more $\mathrm{COF}_{2}$ and which in its turn creates more $\mathrm{CS}_{2}$. Hence, $\mathrm{COF}_{2}$ or $\mathrm{CS}_{2}$ generates a chain reaction that produces an increasing amount of $\mathrm{COF}_{2}$ and $\mathrm{CS}_{2}$. The molecule $\mathrm{CS}_{2}$ is toxic and the molecule $\mathrm{COF}_{2}$ is extremely toxic. It is proposed that long-term cell exposure to $\mathrm{COF}_{2}$ and $\mathrm{CS}_{2}$ may result in reduced apoptosis and uncontrolled cell growth, i.e. cancer.

$\mathrm{COF}_{2}$ and $\mathrm{CS}_{2}$ in a cell line or tumor also act as catalysts outside the cell line and outside the human body by means of their radiated energy [3]. A test tube was positioned outside the cell line or outside the body in the vicinity of the tumor. The test tube contained C (carbon), $\mathrm{F}$ (fluoride) and S (sulfur) dissolved in $\mathrm{H}_{2} \mathrm{O}$ (water). The radiated energy from $\mathrm{COF}_{2}$ acted as catalyst and created $\mathrm{CS}_{2}$ in the test tube. The radiated energy from $\mathrm{CS}_{2}$ acted as catalyst and created $\mathrm{COF}_{2}$. Catalyzes of $\mathrm{COF}_{2}$ and $\mathrm{CS}_{2}$ in a test tube can be used as a cancer marker and 
where the method is non-invasive. Alternatively the test tube may contain only $\mathrm{C}, \mathrm{F}$ and $\mathrm{H}_{2} \mathrm{O}$ wherein only $\mathrm{COF}_{2}$ was created. Alternatively the test tube may contain only $\mathrm{C}, \mathrm{S}$ and $\mathrm{H}_{2} \mathrm{O}$ wherein only $\mathrm{CS}_{2}$ was created. Catalyzes in a test tube can be used as a method to analyze presence of $\mathrm{COF}_{2}$ and $\mathrm{CS}_{2}$ in cell lines or tumors.

$\mathrm{COF}_{2}$ can be analyzed using FTIR (Fourier Transform Infrared Spectrometer), GC (Gas Chromatography) or GC/MS (Gas Chromatography-Mass Spectrometry). $\mathrm{CS}_{2}$ can be analyzed using GC or LC (Liquid Chromatography).

The following types of cancer have been analyzed and they all contain the molecules $\mathrm{COF}_{2}$ and $\mathrm{CS}_{2}$ : brain cancer, breast cancer, colon cancer, larynx cancer, leukemia, liver cancer, lung cancer, lymphatic cancer, melanoma, pancreatic cancer, prostate cancer, squamous cell carcinoma, testicular cancer and uterine cancer.

The following cancer cell lines have been analyzed and they contain the molecules $\mathrm{COF}_{2}$ and $\mathrm{CS}_{2}$ : cellosaurus cell line Mutu-3, lymphoblastic cell line LCL and epithelial cell line HONE-1.

\section{Discussion}

A novel model of cancer is presented. Cancer is created by a mechanism that contains two toxic molecules: $\mathrm{COF}_{2}$ and $\mathrm{CS}_{2}$. They have the ability to reproduce each other wherein a chain reaction occurs that produces vast amounts of $\mathrm{COF}_{2}$ and $\mathrm{CS}_{2}$. $\mathrm{CS}_{2}$ is toxic and $\mathrm{COF}_{2}$ is extremely toxic. It is proposed that they impair the immune system and where the result can be impaired apoptosis and uncontrolled cell growth, i.e. cancer.

Empiric results display that cancer cell lines and cancer tumors act as catalysts wherein they produce $\mathrm{COF}_{2}$ and $\mathrm{CS}_{2}$, also at a distance, i.e. in a test tube positioned outside the cell line or outside the body close to the tumor. Catalyzes of $\mathrm{COF}_{2}$ and $\mathrm{CS}_{2}$ can be used as cancer marker. The method can also be used in order to analyze content of cell lines and tumors, i.e. the cancer causing mechanism.

Reports display correlation between bacterial infections and cancer [5] [6], between viral infections and cancer [7] [8] and between autoimmune diseases and cancer [9] [10]. Recent findings display that many pathogenic bacteria, virus and autoimmune diseases contain a generic part that consists of the molecules $\mathrm{COF}_{2}$ and $\mathrm{CS}_{2}$. These findings will be reported elsewhere. Cancer cannot occur on its own, i.e. without presence of $\mathrm{COF}_{2}$ and/or $\mathrm{CS}_{2}$. Presence of $\mathrm{COF}_{2}$ and/or $\mathrm{CS}_{2}$ is mandatory in order to start the chain reaction where the long-term result is production of vast amounts of $\mathrm{COF}_{2}$ and $\mathrm{CS}_{2}$. Many pathogenic bacteria and viruses as well as autoimmune diseases contain a generic mechanism that consists of the molecules $\mathrm{COF}_{2}$ and $\mathrm{CS}_{2}$. It is proposed that chronic bacterial, viral and autoimmune diseases may start catalyzes of $\mathrm{COF}_{2}$ and $\mathrm{CS}_{2}$ in the infected area. The result is, eventually, a chain reaction that produces vast amounts of $\mathrm{COF}_{2}$ and $\mathrm{CS}_{2}$ and, sometimes, subsequent cancer. Hence, bacterial, viral and autoimmune diseases can initiate a chain reaction where the result is cancer. 
They are not carcinogenic by their own.

Reports display that $\mathrm{Fe}_{2} \mathrm{O}_{3}$ in nanoparticles had a therapeutic effect on cancer cells in vitro and xenograft liver cancer in mice and where the result was increased inhibitory rate and ratio of apoptosis [11]. Another report describes the therapeutic mechanism of treating SMMC-7721 liver cancer cells using $\mathrm{Fe}_{2} \mathrm{O}_{3}$ nanoparticles. It was shown that it could cause cellular necrosis, induce cellular apoptosis and significantly inhibit cellular growth, all of which appeared to be dependent on the concentration of the $\mathrm{Fe}_{2} \mathrm{O}_{3}$ nanoparticles. $\mathrm{Fe}_{2} \mathrm{O}_{3}$ is the active substance in Ferumoxytol [12]. Stanford researchers discovered that Ferumoxytol triggered the immune system to destroy tumor cells [13]. Another study suggests that $\mathrm{Fe}_{2} \mathrm{O}_{3}$ nanoparticles in Ferumoxytol could be applied "off label" to protect the liver from metastatic seeds and potentiate macrophage-modulating cancer immunotherapies [14].

The above studies display a correlation between $\mathrm{Fe}_{2} \mathrm{O}_{3}$ and therapeutic effect on cancer and in particular the therapeutic effect of Ferumoxytol. The following is proposed. $\mathrm{Fe}_{2} \mathrm{O}_{3}$ acts as a catalyst where it reduces (destroys) the molecule $\mathrm{COF}_{2}$ contained in cancer tumors and metastases. However, the molecule $\mathrm{CS}_{2}$ is not destroyed. Destruction of (only) $\mathrm{COF}_{2}$ inhibits further production of $\mathrm{CS}_{2}$ and which limits toxic exposure in cancer tumors and metastases and where the result is increased cellular necrosis and apoptosis. This type of catalyzes can be demonstrated in the following experiment. A test tube containing $\mathrm{COF}_{2}$ was positioned close to 10 grams of $\mathrm{Fe}_{2} \mathrm{O}_{3}$ during 15 minutes. Then the test tube was removed and its content of $\mathrm{COF}_{2}$ was analyzed; the result was zero content of $\mathrm{COF}_{2}$.

\section{Conclusion}

The overall conclusion is that it has been difficult to analyze the cause of cancer using state of the art technique. The present report displays a novel method. Molecules in cancer cell lines and tumors can be analyzed because they radiate energy that causes catalyzes outside the cell line and outside the body in a test tube wherein specific molecules are created $\left(\mathrm{COF}_{2}\right.$ and $\left.\mathrm{CS}_{2}\right)$. These molecules can be analyzed using conventional measurement techniques such as FTIR, GC, GC-MS and LC. The conclusion is also that $\mathrm{Fe}_{2} \mathrm{O}_{3}$ reduces the molecule $\mathrm{COF}_{2}$ and hence, $\mathrm{Fe}_{2} \mathrm{O}_{3}$ may have an important role in cancer therapy.

\section{References}

[1] Garcia-Viloca, M., Gao, J., Karplus, M. and Thrular, D.G. (2004) How Enzymes Work: Analysis by Modern Rate Theory and Computer Simulations. Science, 303, 186-195. https://doi.org/10.1126/science.1088172

[2] Applied Catalysis A: General (2001) Hoelderich Special Issue, 221, 443-457.

[3] Giertz, H.W. (2016) A Novel Model of the Atom. Journal of Modern Physics, 7, 413-421. https://doi.org/10.4236/jmp.2016.75042

[4] Mager, D.L. (2006) Bacteria and Cancer: Cause, Coincidence Or Cure? A Review. Journal of Translational Medicine, 4, 14. https://doi.org/10.1186/1479-5876-4-14 
[5] Daniel, P., et al. (2008) Regulation of the Helicobacter pylori Cellular Receptor Decay-Accelerating Factor. Journal of Biological Chemistry, 283, Article ID 23922. https://doi.org/10.1074/jbc.M801144200

[6] Liao, J.B. (2006) Viruses and Human Cancer. The Yale Journal of Biology and Medicine, 79, 115-122.

[7] Zur Hausen, H. (1991) Viruses in Human Cancers. Science, 22, 1167-1173. https://doi.org/10.1126/science.1659743

[8] Volkers, N. (1999) Do Autoimmune Diseases Raise The Risk of Cancer? Journal of the National Cancer Institute, 1, 1992-1993. https://doi.org/10.1093/jnci/91.23.1992

[9] Rahat, M.A. and Shakya, J. (2016) Parallel Aspects of the Microenvironment in Cancer and Autoimmune Diseases. Mediators of Inflammation, 2016, Article ID 4375120. https://doi.org/10.1155/2016/4375120

[10] Yan, S., et al. (2005) Therapeutic Effect of $\mathrm{Fe}_{2} \mathrm{O}_{3}$ Nanoparticles Combined with Magnetic Fluid Hyperthermia on Cultured Liver Cells and Xenograft Liver Cancers. Journal of Nanoscience and Nanotechnology, 5, 1185-1192.

https://doi.org/10.1166/jnn.2005.219

[11] Yan, S. (2014) Therapeutic Mechanism of Treating SMMC-7721 Liver Cancer Cells with Magnetic Fluid Hyperthermia Using $\mathrm{Fe}_{2} \mathrm{O}_{3}$ Nanoparticles. Brazilian Journal of Medical and Biological Research, 47, 947-959. https://doi.org/10.1590/1414-431X20143808

[12] Neiser, S. (2015) Physico-Chemical Properties of the New Generation IV Iron Preparations Ferumoxytol, Iron Isomaltoside 1000 and Ferric Carboxylmaltose. BioMetals, 28, 615-635. https://doi.org/10.1007/s10534-015-9845-9

[13] Digitale, E. (2016) Iron Nanoparticles Make Immune Cells Attack Cancer. Stanford Medicine News Center.

[14] Zanganeh, S., et al. (2016) Iron Oxide Nanoparticles Inhibit Tumour Growth by Inducing Pro-Inflammatory Macrophage Polarization in Tumour Tissues. Nature Nanotechnology, 11, 986-994. https://doi.org/10.1038/nnano.2016.168 